\title{
THE NOTION OF PERSONAL MORAL CULTURE AND ITS IMPACT ON UKRAINIAN LANGUAGE FORMATION
}

\author{
NATALIIA OLEKSIIENKO
}

\begin{abstract}
This article considers author definition of the notion "moral culture". The present study analyzes theoretical interpretation of the spiritual nature of the language and its impact on the personal moral culture formation. The particular importance should be attached to philosophical, religious, ethical and pedagogical study searches of the existing situation of the research. The problem of Ukrainian language spreading among the youth has been explained. The present study analyzes the problem of mother tongue learning in educational institutions as a basis of moral education. It has been found out that in order to overcome spiritual-moral crisis in modern Ukrainian society, education must be exercised exceptionally in the standard literary Ukrainian language, due to the fact that it is fundamental principle of the moral culture. The necessity of creation not just linguistic identity, with certain totality of language skills, but also nationally conscious linguistic identity so far as it is a pledge of a person and nation moral culture increase.
\end{abstract}

Keywords: moral culture, education, the Ukrainian language, upright specialist, mother tongue, personal culture, moral culture formation.

\section{INTRODUCTION}

Theoretical understanding of the language impact on personal moral culture shaping originates from the moment of its beginning as a system of symbols and signs, with encoded results of cognition and social activity. In the process of research it has been found out that there is little quantity of linguistic works devoted to the spiritual nature of the language in contemporary Ukrainian philology. For a long time, Ukrainian linguists considered language as a means of communication, leaving aside its socio-cultural functions. Changes in language research have been observed from the end of the last century, not just within linguist environment, but also among specialists in culture, philosophy, logics, culture study, psychology, etc. The majority of theories and concepts concerning the place, role and functions of the language in cultural formation of society and identity certify importance of the scientific understanding of the given phenomenon.

The emphasis has been placed on the statements of contemporary Ukrainian scholars (V. Andruschenko, L. Huberskyi, M. Mukhalchenko) whose opinion was that "there cannot be any renovation of the society, formation of national identity, democratic relations application without a regard of culture. Culture enriches nation with common to mankind values, joins person to creativity, brings up economic and moral-ethical features. Therefore, cultural development has to be considered 
alongside with economic and political problems" [1, p. 49]. With the regard to the problem mentioned, we consider the role of specialist language culture of any sphere of activity as a principal in the structure of moral culture.

\section{ANALYSIS AND DISCUSSION}

\subsection{Formation of Personal Moral Culture in the Humanities}

On the basis of literature analysis, thorough study of the latest scientific researches, we defined the notion of "moral culture" as a result of moral development (consciousness and behavior) that reflects the level of morality - totality of opinions, conceptions, norms, evaluations created and declared by humanity, that positively regulates the behavior of individual in practical behavior.

Native philosophy investigates the notion of moral culture on the two levels: general (social) and single (personal). On the general level, particular importance should be attached to the conditions of moral culture education. The aim of the recent past researches was aspiration in strengthening the then social order, giving it at least democratic and human features (V. Andruschenko, V. Danylovych., I. Danylenko, H. Vasianovych, V. Zots, V. Kremen, I. Nadolnyi, V. Shynkaruk and others). These and other scholars investigated world-view and functional roles of moral culture in society, grounded interrelation of common to mankind and national in moral culture.

The main principle of philosophical analysis of moral culture in the period of "perestroika" (reformation) (the middle of the $80^{\text {th }} \mathrm{XX}$ century) is correlation between freedom of society and freedom of personality (single aspect). A lot of scholars (S. de Bovuar, R. Aron, K. Popper, D. Lukach, M. Ponti, A. Lefevere, F. Haek and others) strengthened the idea, according to which loss of freedom in authoritarian society had a negative impact on the level of its moral culture.

In contemporary philosophical studies, particular attention is paid to the role of moral culture in the system of human communication, mutual understanding. This point of view is brightly expressed in philosophical hermeneutics. The main representatives of philosophical hermeneutics (H. Gadamer, W. Dilthey, E. Cassirer, P. Ricoeur, Ju. Habermas, M. Heidegger, F. Shleiermacher) affirm that human being with high level of moral culture aspires to understand other person, due to his/her consciousness, volitional and sensual spheres.

Interesting achievements in the research of contemporary problems of moral culture can be found in religious philosophy. Tireless researcher of Ukrainian culture I. Ohiienko considered moral culture as a positive spiritual value, as a worldview system of moral and cultural knowledge, convictions, feelings and skills, standards and relations, interests and demands, cultural-moral experience and behavior directed at self-completion and personal fulfillment.

The famous Ukrainian thinker and pedagogue H. Vashchenko considered that the essence and content of moral culture was connected with two main phenomena: God and Motherhood. The pedagogue was at the opinion that personal moral culture acquires genuine worth and meaning when proves that it will serve faithfully to native nation, follow Christian Commandments and principles [4, p. 174-175].

Morale culture problem analysis is complemented with searches of ethical opinion representatives. In particular L. Arkhanhelskyi paid particular attention to grounding of moral culture methodological principles, to the place and role of moral consciousness in forward society development, worthwhile aspects of morale culture etc. A. Huseinov devoted his works to the social nature of moral culture, its structure, impact of social environment on personal moral culture formation, interconnection of responsibility, duty, and moral culture etc. Member of the Academy I. Zyazyun profoundly examined scientific and creative inheritance of the famous scholar-psychologist E. Fromm drew a conclusion that nowadays the main problem of the human being is indifference to oneself and his/her moral culture.

The brilliant works of the genius and worldwide known pedagogue, unsurpassed personality Vasyl Sukhomlynskyi played a leading part in the research of moral culture essence and content. In his scientific works, the scholar builds up integral system of personal moral culture formation. The pedagogue put the stress on the fact that every person, regardless sex, age, profession, nationality 
should have high level of moral culture. Without it, one could loss human nature. V. Sukhomlynskyi emphasized on integral unity of two social phenomena: culture and ethics. On the one hand, it is a culture in ethics, on the other hand - explains moral aspect (culture value).

At the present stage Ukrainian scholars also investigate different structural elements of personal moral culture due to the main problems. These are: L. Burdeyna, H. Vasianovych, O. Hordiychuk, V. Hryn'ova, O. Denyschyk, N. Zayachkivska, T. Isaienko, D. Kovalenko, O. Kryvosheyeva, S. Kruk, L. Moskalyova, A. Pavlenko, V. Salko, M. Sitnikova, A. Shemshuryna etc.

On the basis of the given research we state that problem of the essence and content of personal moral culture, methods of its education have always been within eyesight of native and foreign scholars. Taking into consideration these researches, we analyze influence of the Ukrainian language on personal moral culture formation.

\subsection{Role Of the UKRainian LANGUAGE in MORAL CUlture Formation}

The impact of the language on personal moral culture formation is indisputable, the famous philologist O. Radchenko consideres that "language is displayed by strength" [19, p.142]: at home, at school, in the street, in the shop etc. As it generally known, the great thinker W. von Humboldt noticed that language is an influential tool and form of human needs realization and it is a spiritual life of the person, given that functions of the language is a "spirit organism, as well as structure of muscular fiber, circulation of blood, arborization of nerves - body organism" [9, p. 365].

In this context, contemporary linguists N. Nepyivoda and V. Churina assume that language skills in everyday and professional activity are of major importance not just as totality of rules, but also as a culture of living together in society, world view picture, mean of society shaping, and selfexpression" [14].

German philosopher M. Heidegger wrote that language is a spiritual "house of being" and "dwelling of human nature" [5, p. 49]. Therefore, language is a feature of human spiritual life, who takes part in construction of every personality. Ukrainian pedagogue V. Sukhomlynskyi in his groundbreaking conception states that the essence of mother tongue is displayed by irreplaceable basis of personality construction from the moment of birth to extreme old age. In the author's opinion, mother tongue is a foundation of spiritual integrity of human being. V. Sukhomlynskyi considered language culture as a mirror of a human spiritual culture [25, p. 202-212].

Taking into consideration the fact that language is a constituent of moral and spiritual life of a personality, the following scholars V. Zahorodnova, I. Kresina, L. Matsko, L. Skurativskyi, M. Pentylyuk, O. Bilyaev, S. Yermolenko payed particular attention to the necessity of formation not just language personality, that masters certain totality of language skills, but also nationally conscious language personality as far as it is a pledge of general culture level increase.

Pedagogue K. Ushynskyi placed the great emphasis to learning of mother tongue as a basis of personal moral education and "any kind of intellectual development". He supposed that moral and spiritual development takes place when a child masters expressive means of mother tongue, understands not just words, word combinations and modifications, but also a lot of notions, opinions, feelings, artistic images, logic and language philosophy and absorb it easily and quickly...native word - great national pedagogue [26, p. 271].

Any foreign language will never have the same influence on spiritual development of a society as mother tongue has; a foreign language will never penetrate into its spirit and body, never take deep roots with rich and sustainable development. That is why $\mathrm{K}$. Ushynskyi considered that the Ukrainian language teaching was the main subject, and integral part of the other subjects.

Fluent mastery of a mother tongue, its literary standards - is a basis of spiritual and psychological comfort. A question of urgent importance nowadays is adherence to language standards, due to the fact that accuracy is one of the particularly determinant characteristic of speech culture. S. Kalenyuk is on the opinion that: "The main problem of contemporary society is a destruction of the high speech style level, that anticipates using the most important, the richest language words that nourish spiritual side of life". These words are substituted by jargon words, harsh words. This process impoverished and 
narrowed active vocabulary to the critical bound. It is necessary to keep to standards and rules of Ukrainian literary speech, to use in educational institutions. I. Ohiienko supposed that literary language is "the most valuable and important tool of spiritual culture and the strongest cement of unity, the main engine of society spiritual culture development" [15, p.15]. Absence of a literary language can become a reason for nation's features loss, which leads to moral disability. M. Hrushevskui said: "The question of literary language is of particular importance" [8, p.23].

The Ukrainian literary language is profoundly worked up, has a significant history, intellectual potential, and has to be the basis of all subject matters teaching. This is the right of the state and ethnic nation. Indispensable condition of the state's language policy is a compulsory mastering of the state Ukrainian language by all citizens and purposeful efforts of Ukrainian philologists - teachers, lecturers, scientists and methodologists. The language is a criterion of a culture and individuality. As O. Potebnya mentioned "language individuality distinguishes person as individuality and the brighter this individuality is, the better it reflects language characteristics of the society" [18, p. 9].

Nowadays teaching the Ukrainian language in Ukraine has an exceptional meaning. Ya. Yanush says that it can solve the most important problems of contemporary society - problems of youth moral education, studying at secondary and higher educational institutions. Insufficient attention to the Ukrainian language might have a negative influence on the Ukrainian society [28].

Every specialist must understand the importance of the mother tongue teaching influence their formation as individualities. In psychology, scholars drew the conclusion that using a foreign language in everyday life has a very bad influence on the nation and society [17].

Any other language, except national, does not keep balance with above mentioned spheres of human nature and is a bad influence on individual growth. Psychologists state if individuals do not communicate with other people in their mother tongue, they might have the feeling of "language nostalgia", which depresses psyche [24]. "Every student of the higher school first of all has to know the literary language, its pronunciation and spelling" [16, p. 47]. Therefore, in order to overcome spiritual and moral crisis in relations between people, future specialist should learn the standard Ukrainian literary language, because it is a fundamental principle of a moral culture.

Highly educated specialist of any profession should not use "surzhyk", obscene vocabulary, vulgarisms, he must use the language skills that show own professional knowledge and level of culture. Contemporary linguist I. Drozdova notices that "specialist language individuality and language culture is indissoluble. Students have to choose professional vocabulary obtained in the higher educational institution" [11]. Therefore, stating that "Language culture is a general culture of individuality" contemporary scholar N. Forys proves that the world should strive for perfect mastery of the mother tongue in young generation, because it is a means of thoughts and feelings expression [27]. However, the problem of students' language culture is not just pressing, but painful, since it does not meet the needs of the society and their speech culture is the brightest argument of their morality, inner world and culture in general, states T. Hrytsenko [27].

The low level of language culture is the low level of moral and spiritual, professional culture, lack of information about language standards and norms, indifferent attitude to speech, sluggishness of thought, language slovenliness, reluctance to self-control. In our opinion, nowadays, in time of changes, culture of communication plays a significant role in the society.

Youth and public servants, in particular, more often begin to use slang, jargon words, as the result they are not able to accurately formulate thoughts and make up sentences, that is why it is high time to think about language problems. Language accuracy increases work efficiency, helps to find a solution in complicated professional situations. Students have to understand that the level of individual professionalism is defined not just by profound knowledge of the speciality, but ability to be an individual of high moral principles in any situation.

With the help of cultural language, an individual maintains connection with world, which helps to improve spiritual and moral life. In such way, individual adapts to environment and actively changes it. Contemporary linguist $\mathrm{H}$. Sahach points out that obscene words "cripple the soul, body, humiliate individual spirit" [22, p. 146]. "Rotten" words, due to Halyna Sahach, humiliate the spirit of the speaker 
and listener. "Word ecology generates nation's spirit ecology". P. Florenskyi was of the same point of view and stated that firstly word wins the speaker and then the listener. The Bible says "Let a rotten saying not proceed out of your mouth" (Ephesian 4:29). Therefore, accurate pronunciation, personal language culture should generate positive changes, since it lies with it to shape spiritual and moral world of other people.

T. Isaienko considers that contemporary young man, who pretends to be intellectually mature individual, the bearer of moral culture has to operate with knowledge about communicative features of high-quality communication, essence of communication and its mechanisms, principles of communication, communicative situations, behavior models in the process of communication, methods, ways, and ways of information transfer, that realizes the main aim of Ukrainian language learning - formation of nationally conscious, spiritually rich language individuality who has skills and can use language means of communication. Therefore, the Ukrainian language, as a subject, plays a significant role in personality formation. It should be mentioned that a lecturer must not only teach literary language standards, but also love to one's fatherland and cultivate the sense of national and language consciousness.

\section{CONCLUSiOnS}

There are a lot of ways how to educate and improve personal moral culture, but substantial place is taken by language culture. All processes in Ukraine's social life should be conducted in the Ukrainian language, since every science in a foreign language "does not take roots in personality" (I. Ohiienko), does not have "strong influence" on spiritual growth (K. Ushynskyi) and slows down intellectual, psychological, emotional, and moral growth of a personality.

Language policy should be concentrated on the single language mode, due to the fact that struggle for speech culture is a responsibility of every teacher. Every specialist must perfectly master the Ukrainian literary language. Personal speech culture is the brightest indicator of its morality, spiritual world, professionalism and thorough culture development.

\section{REFERENCES}

[1] Andrushchenko V., Gubersky L., Mikhalchenko M. Culture. Ideology. Personality: methodological and ideological analysis. Znannia Ukrainy, Kyiv, 2002. (in Ukrainian)

[2] Arkhanhelsky L. Methodology of ethical studies. Nauka, Moscow, 1982. (in Russian)

[3] Bekh I. Education of the individual: Ascension to spirituality. Lybid, Kyiv, 2006. (in Ukrainian)

[4] Vashchenko H. The educational ideal. Poltavskyi visnyk, Poltava, 1994. (in Ukrainian)

[5] Haidehher M. On the road to language. Litopys, Lviv, 2007. (in Ukrainian)

[6] Holberh M. Dialogue. Understanding. Interpretation. Dialogue of Cultures. Ukraine in the Global Context: Art and Education, 3 (1998), 358-369. (in Ukrainian)

[7] Hrytsenko T. Development of the linguistic personality in technical universities. Humanitarna osvita $u$ tekhnichnykh vyshchykh navchalnykh zakladakh, 17 (2009), 162-172. (in Ukrainian)

[8] Hrushevsky M. History of Ukrainian literature, 1. Veselka, New York, 1959. (in Ukrainian)

[9] Humboldt von. V. Language and philosophy of culture. Nauka, Moscow, 1985. (in Russian)

[10] Huseynov A. Ethics and moral culture of society. Native culture, (1980), 112-128. (in Russian)

[11] Drozdova I. Professional discourse and speech personality of a student of a non-philological higher educational institution. Visnyk of Lviv University: Series philology, $\mathbf{5 0}$ (2010), 212-221. (in Ukrainian)

[12] Isaenko T. Education of the moral culture of personality by means of language. Vytoky pedahohichnoi maisternosti, 12 (2013), 101-106. (in Ukrainian)

[13] Kalenyuk S. Language as a Component of National Culture. Ukrainoznavchyi almanakh, 9 (2012), 87-90. (in Ukrainian) 
[14] Nepyvoda N., Churina V. Language Preparation at School and High School. Ukrainska mova ta literatura, 5 (2000), 9-11. (in Ukrainian)

[15] Ogienko I. The science of native-language duties. Feniks, Lviv, 1995. (in Ukrainian)

[16] Ogienko I. The science of native-language duties: Rhetoric-speaking catechism for teachers. Oberehy, Kyiv, 1994. (in Ukrainian)

[17] Parhonyuk L. To the problem of the language`s essence: some considerations and reflections. Dyvoslovo, 11 (1999), 15-17. (in Ukrainian)

[18] Potebnia A. Aesthetics and poetics. Mystetstvo, Kyiv, 1976. (in Ukrainian)

[19] Radchenko O. Language as a world-view. Linguophilosophical concept of neogumboldtianism. URSS, Moscow, 2006. (in Russian)

[20] Rudenko L. Formation of the communicative culture of future professionals in the field of service in vocational schools: monograph. Piramida, Lviv, 2015. (in Ukrainian)

[21] Savchyn M. Ability of the personality: monograph. Akademiia, Kyiv, 2016.

[22] Sahach G. Temple of the Word: "Heaven on the Earth", 4. PP DM, Rivne, 2006. (in Ukrainian)

[23] Skovoroda G. Song Garden. Selected works: for art. schools age. Veselka, Kyiv, 1983. (in Ukrainian)

[24] Snitko O. The notion of mother tongue in the context of the problems of modern psychology and ethnolinguistics. Naukovi zapysky Kyivskoho natsionalnoho universytetu im. T. H. Shevchenka. In-t filolohii, 13 (2004), 15-18. (in Ukrainian)

[25] Sukhomlinsky V. Selected works in 5 t., 3. Rad. shkola, Kyiv, 1977. (in Ukrainian)

[26] Ushinsky K. Works in 6 t., 1. Rad. shkola, Kyiv, 1954. (in Russian)

[27] Foris N. From the culture of speech - to the general culture of man. Ukr. mova y lit. v serednikh shkolakh, himnaziiakh, litseiakh ta kolehiumakh, 1 (2004), 79-85. (in Ukrainian)

[28] Yanush Ya. The role of the Ukrainian language in the education of students. Duvoslovo, 4 (2005), 37-39. (in Ukrainian)

Address: Nataliia Oleksiienko, Lviv State University of Life Safety, 35, Kleparivska Str., Lviv, 79000, Ukraine.

E-mail: N.Kapitan@ukr.net.

Received: 15.12.2017; revised: 26.03.2018.

Олексієнко Наталія. Сутність моральної культури особистості та вплив української мови на ії формування. Журнал Прикарпатського університету імені Василя Стефаника, 5 (1) (2018), 150-155.

У статті подано авторське визначення поняття “моральна культура". Проаналізовано теоретичне осмислення духовної природи мови та ії вплив на формування моральної кудьтури особистості. Значна увага приділяеться питанням з'ясування загальнофілософських, релігійних, етичних і педагогічних пошуків вивчення сучасного стану цієї проблеми. Висвітлено проблему поширення української мови серед мододі. Здійснено аналіз питання вивчення рідної мови у навчальних закладах як основи морального виховання особистості. 3'ясовано, що для подолання духовно-моральної кризи в сучасному українському соціумі навчання має відбуватися викдючно українською літературною мовою з усіма ії вимогами, адже це є першоосновою моральної культури. Обгрунтовано необхідність формування не просто мовної особистості, яка володіє певною сукупністю мовних знань і навичок, а національно свідомої мовної особистості, оскільки це є запорукою підвищення рівня моральної кудьтури людини та нації.

Ключові слова: моральна культура, освіта, українська мова, високоморальний фахівець, рідна мова, культура особистості, формування моральної культури. 